\title{
Spectrophotometric methods for the determination of photosynthetic pigments in stratified lakes: a critical analysis based on comparisons with HPLC determinations in a model lake
}

\author{
Antonio Picazo, Carlos Rochera, Eduardo Vicente, Maria Rosa Miracle and Antonio Camacho*
}

Cavanilles Institute of Biodiversity and Evolutionary Biology \& Department of Microbiology and Ecology, University of Valencia, Dr. Moliner 50, E-46100 Burjassot, Valencia, Spain.

* Corresponding author: antonio.camacho@uv.es

Received: 5/11/12 Accepted: 25/2/13

\begin{abstract}
Spectrophotometric methods for the determination of photosynthetic pigments in stratified lakes: a critical analysis based on comparisons with HPLC determinations in a model lake

High-performance liquid chromatography (HPLC) is an accurate method for photosynthetic pigment analysis; however, spectrophotometric equations are also frequently used for pigment quantification in aquatic systems. Here, we present a critical analysis of the most-used spectrophotometric equations by comparing the results obtained using these equations with unambiguous HPLC determinations. The study was performed in Lake La Cruz (central Spain). In this meromictic lake with strong thermal stratification, photosynthetic populations occur in different, vertically stratified layers. Eukaryotic algae and picocyanobacteria are mostly located in oxic layers, whereas purple sulphur bacteria grow at the oxic-anoxic interface and below, and green sulphur bacteria occur primarily in deeper anoxic layers. This broad diversity of photosynthetic microorganisms involves a complex mixture of photosynthetic pigments that often exhibit overlapping absorption spectra. We tested spectrophotometric equations using samples that represented the entire range of spatial and temporal variability of the lake. For chlorophyll- $a$, the best correlations with all tested equations were observed for oxic layers. Regardless of where the sample was obtained, the best fit for chlorophyll- $a$ was produced by the equation of Overmann \& Tilzer, which is specifically designed to handle mixtures of chlorophyll- $a$ and bacteriochlorophyll- $d$ from green sulphur bacteria. Trichromatic equations for determining chlorophyll $b$ and $-c$ exhibited strong interferences in anoxic waters, whereas in the upper layers of the lake, concentrations of these pigments were usually below the detection limit, restricting the use of these equations. The equations of Takahashi \& Ichimura for bacterial pigments slightly overestimated both bacteriochlorophyll- $a$ and $-d$ by approximately $10 \%$ and underestimated bacteriochlorophyll- $c$ by nearly $23 \%$, although for bacteriochlorophyll- $d$, the correlation was better than those obtained using the dichromatic equations of Parkin \& Brock and Overmann \& Tilzer, respectively. Total carotenoid abundance can be assessed with the equation designed for this purpose by Strickland \& Parsons (1972); however, the accuracy of the results differs with depth and is strongly biased by the presence of the bacterial carotenoid okenone. On the other hand, dual-wavelength carotenoid-to-chlorophyll- $a$ ratios (430/665 and 480/665) only produced acceptable results in the epilimnion, with the occurrence of the bacterial carotenoid okenone in the microaerobic and anoxic layers again producing significant interference. Additionally, the wide variation with depth of the carotenoid composition undermined the validity of these dual-wavelength ratios. In conclusion, our findings indicate that a complete and unambiguous study of photosynthetic pigments in highly stratified lakes with overlapping populations of phototrophic microorganisms requires the use of HPLC techniques. Anyway, our results demonstrate that chlorophyll- $a$ and bacteriochlorophyll- $a$ and $-d$ can be directly measured in oxic and anoxic layers, respectively, using spectrophotometric methods with an error lower than $10 \%$. However, according to our results, chlorophyll- $b$ and $-c$ and bacteriochlorophyll- $c$ cannot be accurately estimated by spectrophotometric methods in stratified lakes.
\end{abstract}

Key words: Stratified lakes, photosynthetic pigments, chlorophylls, bacteriochlorophylls, spectrophotometry, high performance liquid chromatography (HPLC), phytoplankton, photosynthetic bacteria. 


\begin{abstract}
RESUMEN
Determinación de pigmentos fotosintéticos por métodos espectrofotométricos en lagos estratificados: un análisis crítico basado en la comparación con determinaciones por HPLC en un lago modelo
\end{abstract}

La cromatografía líquida de alta eficacia (HPLC) es un método preciso para el análisis de pigmentos fotosintéticos, sin embargo las ecuaciones espectrofotométricas todavía se usan frecuentemente en sistemas acuáticos. En este trabajo mostramos un análisis crítico de algunas de estas ecuaciones comparando los resultados obtenidos con las determinaciones más precisas realizadas por HPLC. El estudio se realizó tomando como modelo la Laguna de La Cruz (centro de España). En este lago meromíctico, que además presenta una fuerte estratificación térmica estival, las poblaciones de microorganismos fotosintéticos se sitúan verticalmente estratificadas en diferentes capas. Mientras que las algas eucariotas y las picocianobacterias se localizan en las capas óxicas, las bacterias púrpuras del azufre crecen en la interfase óxico-anóxica y por debajo de esta y las bacterias verdes del azufre se localizan en capas anóxicas más profundas. Esta amplia diversidad de microorganismos fotosintéticos implica una compleja mezcla de pigmentos fotosintéticos en los extractos, los cuales a menudo muestran espectros de absorción que se superponen. Hemos ensayado las ecuaciones espectrofotométricas con muestras que abarcan toda la variabilidad espacial y temporal del lago. Para la clorofila-a encontramos buenas correlaciones en las capas óxicas para la mayoría de las ecuaciones ensayadas. Sin embargo, la ecuación que mejor funciona en general para la determinación de la concentración de clorofila-a, independientemente del origen de la muestra, es la dada por Overmann \& Tilzer, que está diseñada específicamente para mezclas de clorofila-a con bacterioclorofila-d de bacterias verdes del azufre. Las ecuaciones tricromáticas para la determinación de clorofila-b y c presentaron fuertes interferencias en aguas anóxicas, mientras que en las capas superiores del lago las concentraciones se encontraron normalmente por debajo del límite de detección, lo que restringía la posibilidad de uso de estas ecuaciones. Las ecuaciones de Takahashi \& Ichimura (1970) para pigmentos bacterianos sobreestimaban tanto la concentración de bacterioclorofila-a como la d, aproximadamente en un $10 \%$, y subestimaban la concentración de bacterioclorofila-c casi en un $23 \%$; si bien para la determinación de bacterioclorofila-d la correlación fue mejor que la obtenida por las ecuaciones dicromáticas de Parkin \& Brock y de Overmann \& Tilzer. La abundancia de carotenos totales puede ser estimada por la ecuación de Strickland \& Parsons (1972) diseñada para este propósito, sin embargo la precisión en los resultados difiere con la profundidad y se ve tremendamente sesgada por la presencia del caroteno bacteriano okenona. Por otro lado, las relaciones caroteno/clorofila-a basada en medidas a doble longitud de onda (430/665 y 480/665) solo mostraban resultados aceptables en el epilimnion, ya que en otras capas la aparición de carotenos bacterianos como la okenona produce interferencias significativas. Además, la gran variación en profundidad de la composición de carotenos socava la validez de estas relaciones fundamentadas en medidas a doble longitud de onda. En conclusión, nuestros resultados indican que el estudio de los pigmentos fotosintéticos completo y sin ambigüedades en lagos fuertemente estratificados y con solapamiento de sus poblaciones de organismos fototróficos requiere del uso de HPLC. Sin embargo, nuestros resultados también demuestran que las concentraciones de clorofila-a y bacterioclorofila-a y d pueden ser directamente medidas, tanto en profundidades óxicas como anóxicas, usando ecuaciones espectrofotométricas con un error inferior a un $10 \%$. Por el contrario, de acuerdo con nuestros resultados ni la concentración de clorofila-b y c, ni la de bacterioclorofila-c pueden ser estimadas con precisión por métodos espectrofotométricos en lagos estratificados.

Palabras clave: Lagos estratificados, pigmentos fotosintéticos, clorofilas, bacterioclorofilas, espectrofotometría, cromatografía líquida de alta eficacia (HPLC), fitoplancton, bacterias fotosintéticas.

\section{INTRODUCTION}

Since the early days of research in limnology, the correct quantification of photosynthetic pigments has been a topic of great interest. For many years, spectrophotometric methods were the only methods available for pigment quantification and were an important concern in limnology. Despite the more recent appearance of chromatographic techniques (High Performance Liquid Chromatography-HPLC) for quantifying pigments, it seems advisable to continue using spectroscopic techniques and use chro- matographic techniques to calibrate previously obtained results. Questions related to the best methods for quantifying pigments have been raised for a long time, primarily in seawater and in non-stratified systems (Murray et al., 1986; Salinas, 1988; Pinckney et al., 1994; Latasa et al., 1996; Mantoura et al., 1997; Dos Santos et al., 2003; Ritchie, 2008; Jodłowska \& Latała, 2011). However, there is a lack of information for highly stratified systems with a complex mixture of photosynthetic organisms in the vertical profile and marked seasonal changes in those organisms' relative abundances. 
Conventionally, limnological studies use chlorophyll- $a$ concentration, the analysis of which is faster than cell counting procedures, to estimate phytoplankton biomass and/or primary productivity. Chlorophyll- $a$ concentration is also a common and reliable indicator of water quality and trophic status used in management routines. The analytical differentiation of photosynthetic pigments is valuable for elucidating the composition of phytoplankton communities because some pigments are chemotaxonomic biomarkers (Wright \& Jeffrey, 2006). In this context, chlorophyll- $a$ is a universal marker of phytoplankton abundance, but chlorophyll- $b$ and $-c$ can be good indicators of the abundance of specific algal groups such as chlorophytes or bacillariophytes/chrysophytes, respectively. Accordingly, chlorophyll $b / a$ and $c / a$ ratios have been suggested as proxies of the relative dominance of these algal groups (MacLulich, 1986). In anoxic waters such as the anoxic hypolimnion of stratified lakes and reservoirs or the monimolimnion of meromictic lakes, it is also possible to assess the biomass and structure of the photosynthetic bacterial community through the quantification of the different bacteriochlorophylls. Furthermore, the total or relative concentration of carotenoids has long been used to investigate the physiological condition of phytoplankton populations, which may vary depending on light conditions (Jodłowska \& Latała, 2011) or nutrient availability (Shimura \& Fujita, 1975). In this context, the carotenoidto-chlorophyll- $a$ ratio has been proposed as a measure of the accumulation of fatty acids in freshwater microalgae, which co-occurs with nitrogen starvation or light stress (Solovchenko et $a l ., 2009)$. These simple relationships among pigments can thus be considered as tentative proxies of the physiological status of algal populations, with results that are more practical than those of more complex and expensive approaches.

The spectrophotometric methods for quantifying photosynthetic pigments in samples containing pigments from different sources are based on conventional visible absorbance measurements of organic extracts. In this case,
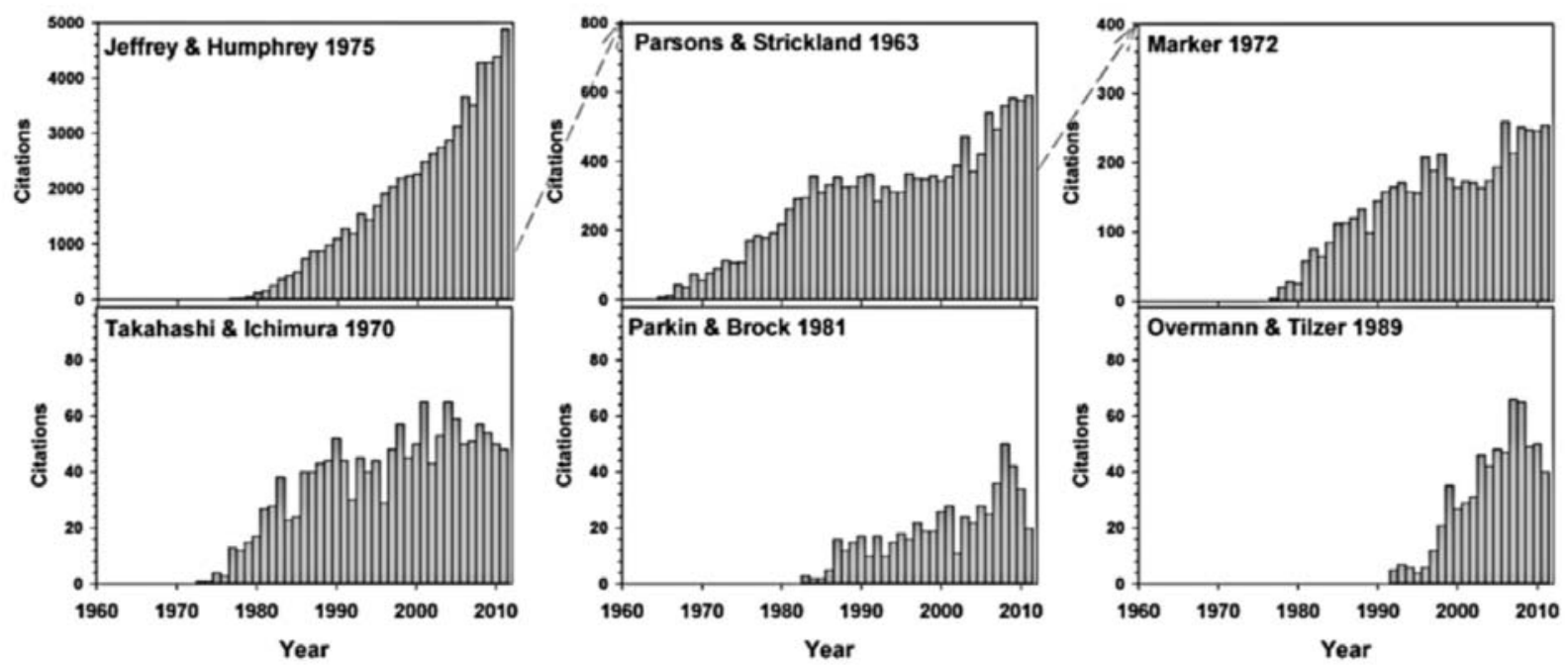

Figure 1. Summary of citations, by year of publication, of the most-used equations in the spectrophotometric determination of the photosynthetic pigments that were tested in our study (source: ISI -Thomson Reuters, Web of Knowledge). The equations proposed by Parsons \& Strickland (1963) are most commonly cited as Strickland \& Parsons (1972) from their Seawater Analysis Manual, and consequently, the number of citations in ISI-WOK under represents their usage. Note the differences in scale for the number of citations. Informe de citas, por año de publicación, de los métodos de cálculo más utilizados en la determinación espectrofotométrica de pigmentos fotosintéticos y analizados en este estudio (fuente: ISI-Thomson Reuters, Web of Knowledge). Las ecuaciones de Parsons \& Strickland (1963) se citan normalmente refiriendo el manual de análisis de aguas marinas de Strickland \& Parsons (1972), por lo que los datos de la cita del artículo de 1963 obtenido del ISI-WOK estarían subestimando el uso real de estas ecuaciones. Nótese las diferentes escalas para el número de citaciones. 
pigments can be extracted from cells using different organic solvents such as acetone, methanol, ethanol, diethyl ether, dimethyl sulfoxide (DMSO) or dimethyl formamide (DMF). Acetone is probably the most-used solvent (Ritchie, 2006), as it produces sharper absorption peaks compared to other solvents. On the other hand, it is more volatile and flammable than other solvents. Acetone is also considered to be less efficient at extracting pigments compared to other solvents (Ritchie, 2006); however, pigment recovery can be improved in different ways, such as by using sonication (Schagerl \& Künzl, 2007).

The methods used for pigment quantification vary in accuracy and cost-effectiveness. Quantification by HPLC allows the discrimination of chlorophyll, its derivatives and carotenoids (Mantoura \& Llewellyn, 1983). HPLC further improves the pigment detection limit in comparison to other methods, but also requires the use of expensive instruments and the need for certain technical capabilities for data processing. By contrast, the direct spectrophotometric quantification of samples containing a mixture of pigments is more affordable and widely used today (Fig. 1). A standardised HPLC protocol for photosynthetic pigment determination has already been compiled in the 21 st edition of the APHA Standard Methods (2005). However, the management agencies responsible for controlling water quality, such as the US EPA in its Method 447.0 (Arar, 1997), still recommend spectrophotometric methods, for instance, that of Jeffrey \& Humphrey (1975). The direct spectrophotometric quantification of a mixture of pigments requires the use of equations that utilise molar

Table 1. The most-used equations for the spectrophotometric determination of the photosynthetic pigments that were tested in this study. (v: acetone volume added for extraction, V: Total water volume filtered for pigment extraction). (TC: Total number of citations, ACI: Average Citations per Item, SPU: Specified plant pigments units). Ecuaciones más usadas para la determinación espectrofotométrica de los pigmentos fotosintéticos testados en este estudio. (v: Volumen de acetona añadido para la extracción, $V$ : Volumen total de agua filtrado para la extracción). (TC: Número total de citas, ACI: Media de citas por item, SPU: Unidades de pigmentos específicos).

\begin{tabular}{|c|c|c|c|c|c|}
\hline Monochromatic & & & & $\mathrm{TC}$ & $\mathrm{ACI}$ \\
\hline Marker 1972 & Chl $a$ & $\left(\mu \mathrm{g}^{-1}\right)$ & $13.14 * \mathrm{DO} 665 *(\mathrm{v} / \mathrm{V})$ & 5359 & 33.08 \\
\hline \multicolumn{6}{|l|}{ Dichromatic $(\mathrm{Chl} a$-Bchl $d)$} \\
\hline Parkin \& Brock 1981 & $\operatorname{chl} a$ & $\left(\mu g 1^{-1}\right)$ & $11.9 * \mathrm{DO} 663 *((\mathrm{DO} 663 / \mathrm{DO} 654 * 0.93)-0.33 *(\mathrm{v} / \mathrm{V})$ & 593 & 21.18 \\
\hline Overmann \& Tilzer 1989 & $\begin{array}{l}\mathrm{Bchl} d \\
\quad \operatorname{chl} a \\
\mathrm{Bchl} d+e\end{array}$ & $\begin{array}{l}\left(\mu g 1^{-1}\right) \\
\left(\mu g 1^{-1}\right) \\
\left(\mu g 1^{-1}\right)\end{array}$ & $\begin{array}{l}10.2 * \mathrm{D} 654((\mathrm{DO} 663 / \mathrm{DO} 654 *(-0.99)+1.55) *(\mathrm{v} / \mathrm{V}) \\
(1.315 * \mathrm{DO} 663-0.643 * \mathrm{DO} 651+0.005) * \mathrm{v} * 10^{3} /(\mathrm{V} * \mathrm{~d} * 84) \\
(1.315 * \mathrm{DO} 651-0.643 * \mathrm{DO} 663+0.005) * \mathrm{v} * 10^{3} /(\mathrm{V} * \mathrm{~d} * 98)\end{array}$ & 684 & 23.59 \\
\hline \multicolumn{6}{|l|}{ Trichromatic } \\
\hline \multirow[t]{3}{*}{ Strickland \& Parsons 1972} & Chl $a$ & $\left(\mu \mathrm{g} 1^{-1}\right)$ & 11.6*DO665-1.3*DO645-0.14*DO630*(v/V) & 13441 & 34.91 \\
\hline & Chl $b$ & $\left(\mu g 1^{-1}\right)$ & $20.7 *$ DO645-4.34*DO665-4.42*DO630*(v/V) & & \\
\hline & Chl $c$ & $\left(\mu g 1^{-1}\right)$ & $55 * \mathrm{DO} 630-4.64 * \mathrm{DO} 665-16.3 * \mathrm{DO} 645 *(\mathrm{v} / \mathrm{V})$ & & \\
\hline \multirow[t]{3}{*}{ Jeffrey \& Humphrey 1975} & Chl $a$ & $\left(\mu g 1^{-1}\right)$ & $11.85 *$ DO664-1.54*DO647-0.08*DO630*(v/V) & 66647 & 29.53 \\
\hline & Chl $b$ & $\left(\mu \mathrm{g}^{-1}\right)$ & $-5.47 * \mathrm{DO} 664+21.03 * \mathrm{DO} 647-2.66 * \mathrm{DO} 630 *(\mathrm{v} / \mathrm{V})$ & & \\
\hline & Chl $c$ & $\left(\mu \mathrm{g}^{-1}\right)$ & $-1.67 * \mathrm{DO} 664-7.60 * \mathrm{DO} 647+24.52 * \mathrm{DO} 630 *(\mathrm{v} / \mathrm{V})$ & & \\
\hline \multicolumn{6}{|l|}{ Bacterioclorophylls } \\
\hline \multirow[t]{4}{*}{ Takahashi \& Ichimura 1970} & $\mathrm{Bchl} a$ & $\left(\mu g 1^{-1}\right)$ & $25.2 * \mathrm{DO} 772 *(\mathrm{v} / \mathrm{V})$ & 1489 & 21.58 \\
\hline & Bchl $c$ & $\left(\mu g 1^{-1}\right)$ & $10.8 * \mathrm{DO} 662 *(\mathrm{v} / \mathrm{V})$ & & \\
\hline & Bchl $d$ & $\left(\mu g 1^{-1}\right)$ & $10.2 * \mathrm{DO} 654 *(\mathrm{v} / \mathrm{V})$ & & \\
\hline & $\operatorname{Bchl} e$ & $\left(\mu g 1^{-1}\right)$ & $10.2 * \mathrm{DO} 652 *(\mathrm{v} / \mathrm{V})$ & & \\
\hline
\end{tabular}

Carotenoids

Strickland \& Parsons 1972 Carotenoids $\left(\mu \mathrm{SPU} 1^{-1}\right) 4 * \mathrm{DO} 480 *(\mathrm{v} / \mathrm{V})$

Index 430/480 Car/chl- $a$ ratio _ DO430/DO665

Index 480/665 Car/chl- $a$ ratio _ DO480/DO665 
extinction coefficients for each specific pigment (Table 1). These equations may use only one extinction coefficient (i.e., monochromatic) or include several coefficients to minimise the interference produced by overlapping absorption spectra (i.e., trichromatic). Spectrophotometric analyses may yield divergent results depending on which equation is used (Mantoura et al., 1997).

Stratified lakes and reservoirs presenting oxic-anoxic interfaces support plankton communities whose composition can notably differ in its content of photosynthetic pigments (Steenbergen \& Korthals 1982). Furthermore, the spatial distributions of different groups of these diverse phototrophs usually overlap within the water column (Miracle et al., 1992, Camacho et al., 2001). In deeper water, anoxia and the characteristics of the light that penetrates to greater depths in these lakes allow the development of photosynthetic bacterial populations (Takahashi \& Ichimura, 1970), which coexist with settled senescent epilimnetic phytoplankton and unicellular picocyanobacteria, forming deep chlorophyll maxima. All of these factors increase the pigment complexity of samples, thus intensifying the previously addressed impreciseness of spectrophotometric measures (Stal et al., 1984).

The strength and suitability of some spectrophotometric algorithms in stratified lakes are considered in this study by challenging the results obtained with spectrophotometric equations with reliable quantifications performed on chromatographically isolated pigments. The study was conducted with samples from meromictic Lake La Cruz, situated in central Spain, which was selected as a model lake because it presents the most possible combinations of overlapping microorganisms within its different vertical gradients. In addition to its permanent monimolimnion, this lake annually develops a strong thermal stratification and a relatively complex distribution of different photosynthetic microorganisms along its vertical profile. From the results of this analysis, we provide recommendations to be considered before undertaking limnological studies in this type of multi-layered

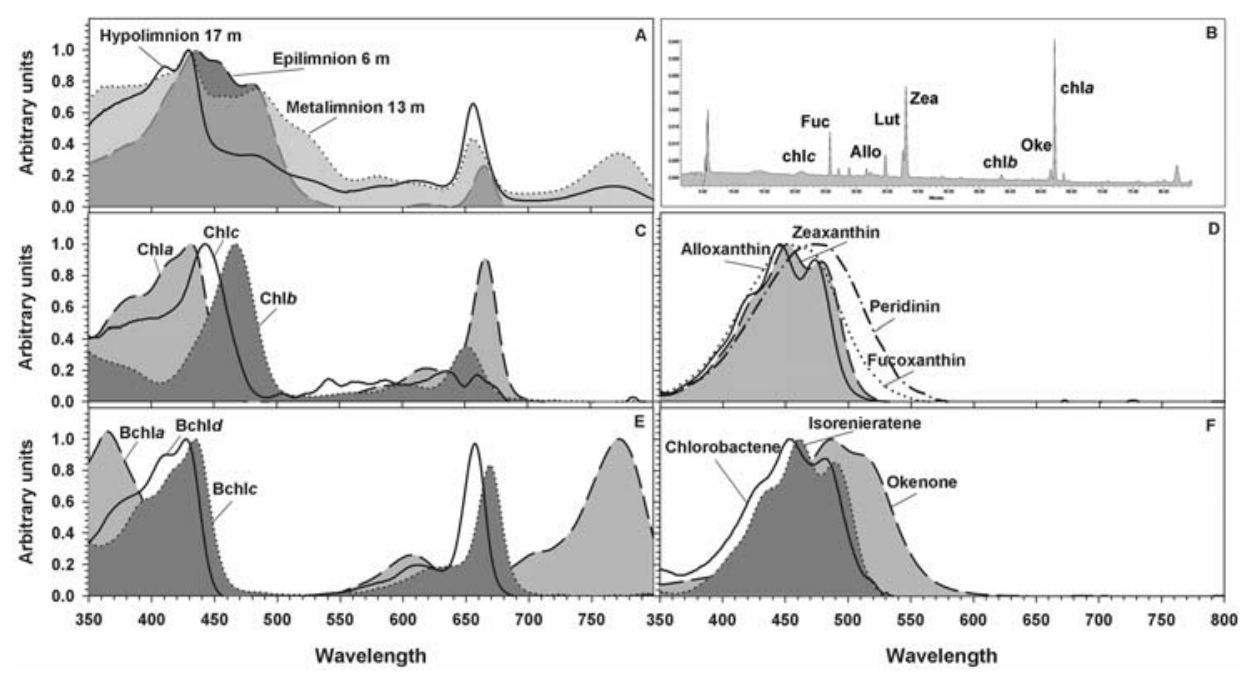

Figure 2. A) Spectrophotometric absorption spectra of the pigment extracts from samples collected from different depths (epilimnion, metalimnion and hypolimnion) of Lake La Cruz in June 2006. B) HPLC profile of a sample from the metalimnetic waters of Lake La Cruz collected in June 2006. C and D) Individual absorption spectra of the most abundant photosynthetic pigments in oxic waters of Lake La Cruz. E and F) Individual absorption spectra of the most abundant photosynthetic pigments in anoxic waters of Lake La Cruz. (All individual data spectra from HPLC profiles, samples collected June 2006). A) Espectros de absorción espectrofotométricos de los pigmentos extraídos a diferentes profundidades (epilimnion, metalimnion e hipolimnion) en la Laguna de La Cruz, junio 2006. B) Perfiles por cromatografía líquida (HPLC) de una muestra de aguas metalimnéticas de la Laguna de La Cruz, junio 2006. C y D) Espectros de absorción individuales de los pigmentos fotosintéticos más abundantes en las aguas óxicas de la Laguna de La Cruz. E y F) Espectros de absorción individuales de los pigmentos fotosintéticos más abundantes en las aguas anóxicas de la Laguna de La Cruz. (Todos los datos de los espectros individuales provienen de los perfiles de HPLC, en muestras de junio de 2006). 
and complex freshwater environment, attempting to establish the particular trade-offs that can occur when using these equations. In this sense, our study aims to facilitate the selection of simple spectrophotometric methods in stratified water columns when the application of more expensive procedures such as HPLC is not suitable, primarily by considering that spectrophotometric methods are the most common means of obtaining certain key limnological data.

\section{METHODS}

\section{Study site}

Samples for pigment analysis were collected from Lake La Cruz, a meromictic karstic lake situated in a doline in Cañada del Hoyo (Cuenca, central Spain) (UTM 30 X596163 Y4427009, datum WGS84) with a surface area of $10,100 \mathrm{~m}^{2}$ and a maximum depth of 21 meters. This lake exhibits a strong thermal stratification that develops each year between April and October (Camacho et al. 2003) and a permanently anoxic monimolimnion (Vicente \& Miracle, 1988; Rodrigo et al., 2000, 2001). The water samples were obtained following the procedures described in Miracle et al. (1992). The samples used for the study correspond to 12 limnological surveys conducted between December 2005 and January 2007 and include a total of 235 samples obtained throughout the vertical profile, 144 and 91 from oxic and anoxic layers, respectively (Fig. 2).

\section{Pigment extraction procedure}

For pigment extraction, the seston was recovered by filtering water from each depth layer through GF/F filters (Whatman $47 \mathrm{~mm}$ ). After that, the filters were placed on corning tubes containing $5 \mathrm{ml}$ of $90 \%$ acetone (modified from Strickland \& Parsons 1972). To facilitate the extraction, samples were sonicated several times. Samples were later stored at $-20^{\circ} \mathrm{C}$ in the dark for at least 8 hours. After this, the tubes were centrifuged $(3000 \times \mathrm{g}$ for $10 \mathrm{~min})$ and the pellet discarded. The supernatant was then filtered onto
PTFE $0.2 \mu \mathrm{m}$ filters (VWR) and processed within the following 3 hours. The spectrophotometric and HPLC determinations were made in parallel with two aliquots from the same extract.

\section{Pigment determination by VIS-spectrophotometry}

Spectrophotometric measurements were performed with $2 \mathrm{ml}$ of filtered extract in $1 \mathrm{~cm}$ quartz cuvettes using a Beckman DU-7 UVVisible spectrophotometer. The scan spectra from 350 to $900 \mathrm{~nm}$, with a resolution of $0.5 \mathrm{~nm}$, were digitally recorded and processed. The concentrations of different photosynthetic pigments were obtained using the algorithms compiled in Table 1.

\section{Pigment determination via high-performance liquid chromatography (HPLC)}

To analyse pigment composition using HPLC, a $150 \mu \mathrm{l}$ aliquot of each extract was injected into a Waters HPLC system with a Waters 996 photodiode Array Detector. To improve the separation of pigments, before injection, the aliquots were mixed with a volume of ammonium acetate (ion pairing agent) to reach a final concentration of $0.1 \mathrm{mM}$. The system was equipped with two columns (Spherisorb S5 ODS2) working in series and running for $95 \mathrm{~min}$ at $35^{\circ} \mathrm{C}$ in a methanol/ammonium acetate/acetone gradient modified from Pinckney et al. 1996 to improve separation (see gradient in Table 2). Eluted pigments were detected by a photodiode array detector at a range of absorbance of 380-800 nm. The peak identities were determined by comparing the retention times and spectra with either pure standards purchased from DHI $\mathrm{R}$ or chromatograms acquired from pure algal or sulphur bacterial cultures. The pigment concentrations were obtained from the curves made with the standards by integrating the area under the crosssection at the wavelength of maximum absorption of each pigment. In all cases, linear correlations were measured with the intercept forced to zero. For some algae carotenoids and all bacterial pigments, concentrations were calculated us- 
Table 2. Solvent gradient applied for HPLC measurements (after Pinckney et al., 1996). Gradientes de los diferentes solventes aplicados en las medidas por HPLC (según Pinckney et al., 1996).

\begin{tabular}{ccccc}
\hline Time $(\mathrm{min})$ & Flow $\left(\mathrm{ml} \mathrm{min}^{-1}\right)$ & \% Methanol & \% Ammonium acetate $(0.1 \mathrm{M})$ & $\%$ Acetone \\
\hline 0 & 0.8 & 80 & 20 & 0 \\
5 & 0.8 & 80 & 10 & 10 \\
45 & 1.25 & 80 & 5 & 15 \\
50 & 1.5 & 80 & 0 & 20 \\
65 & 0.8 & 80 & 0 & 20 \\
67 & 0.8 & 80 & 20 & 0 \\
95 & 0.8 & 80 & 20 & 0 \\
\hline
\end{tabular}

ing specific extinction coefficients (Foppen, 1971 \& Jeffrey et al., 1997).

\section{Data analyses}

For each studied pigment, the Pearson correlation coefficient was used to evaluate the agreement between measures performed by spectrophotometry and HPLC. Student t-tests were performed to determine whether the Pearson correlation coefficients were statistically significant, establishing a confidence value of $p \leq 0.05$. The slopes of the correlations indicated whether the equations underestimated or overestimated pigment concen-
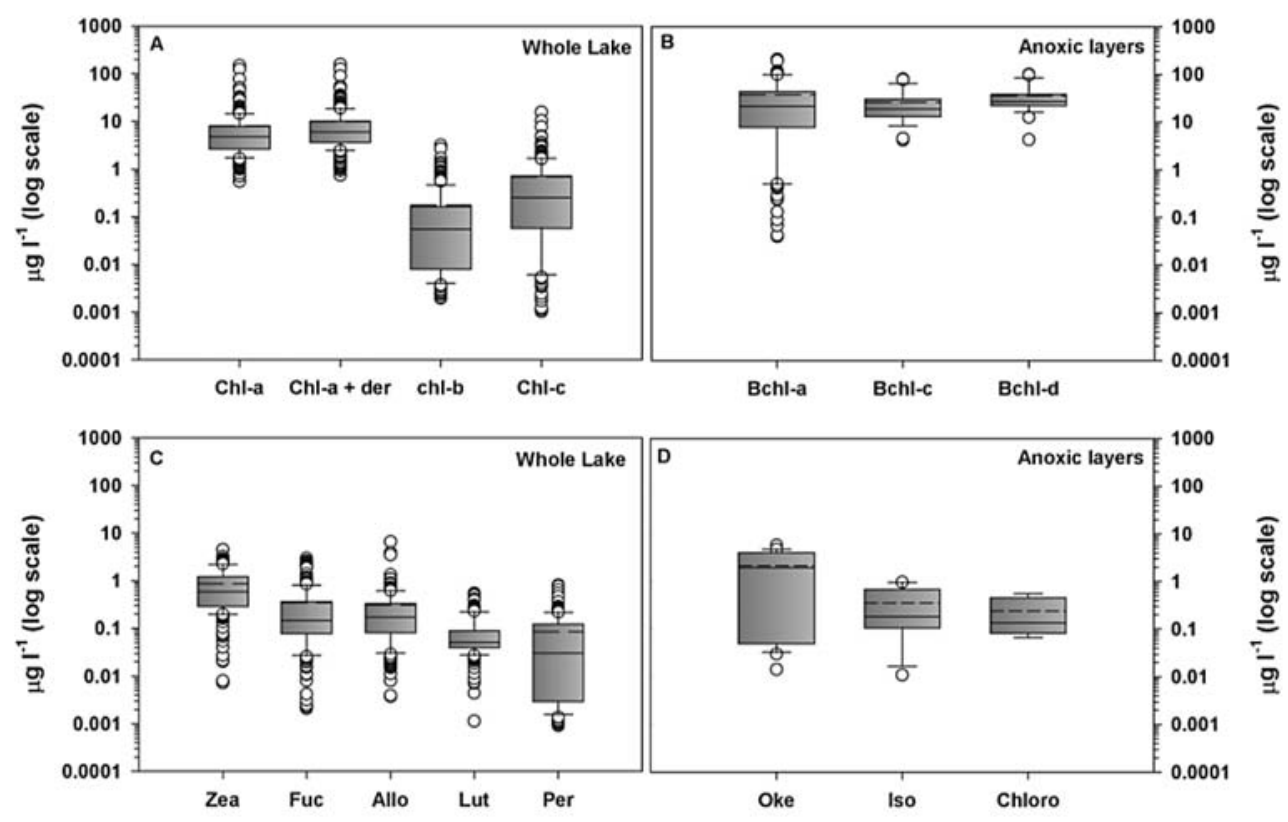

Figure 3. Box-plot distribution ( $\log$ of concentration, $\left.\mu \mathrm{g}^{-1}\right)$ ) of the most abundant photosynthetic pigments found in Lake La Cruz. The statistical parameters of the raw data set used in this study are shown. A) Chlorophyll- $a$, plus derivatives, $b$ and $c$ in all of the samples. B) Bacteriochlorophyll- $a, c$ and $d$ in the samples from anoxic waters. C) Primary algae or cyanobacterial carotenoids in all of the samples (Zea: Zeaxanthin, Fuc: Fucoxanthin, Alo: Alloxanthin, Lut: Lutein, Per: Peridinin). D) Primary bacterial carotenoids in samples from anoxic waters (Oke: Okenone, Iso: Isorenieratene, Chloro: Chlorobactene). Diagrama de cajas de la distribución (logaritmo de la concentración $\left(\mu g l^{-1}\right)$ ) de los pigmentos fotosintéticos más abundantes encontrados en la laguna de La Cruz. Se muestran los datos estadísticos en bruto usados en el presente estudio. A) Clorofila-a y derivados, b y c en todas las muestras B) Bacterioclorofilas-a, c y d en muestras de aguas anóxicas. C) Principales carotenos de algas y cianobacterias en todas las muestras (Zea: Zeaxantina, Fuc: Fucoxantina, Alo: Alloxantina, Lut: Luteina, Per: Peridinina). D) Principales carotenos bacterianos en muestras de aguas anóxicas (Oke: Okenona, Iso: Isorrenierateno, Chloro: Clorobacteno). 
trations. All of the data correlations and statistical analyses were performed using University of Valencia-licensed SPSS 17.0 software.

\section{RESULTS}

During the studied period, the concentrations of all of the analysed photosynthetic pigments showed high variability (Fig. 3 ). In the entire water column, the concentration of chlorophyll- $a$ varied from 0.5 to $85 \mu \mathrm{g} \cdot \mathrm{l}^{-1}$ and its derivatives (primarily chlorophyllide and pheophytin) represented between 3 and $60 \%$ of the total chlorophyll- $a$ concentration, with a high degree of variability within the vertical profile and over time. We observed pigment concentrations below the detection limit of the spectrophotometric method (i.e., $0.5 \mu \mathrm{g} \cdot \mathrm{1}^{-1}$ ) in $89 \%$ of the samples for chlorophyll- $b$ and in $61 \%$ for chlorophyll- $c$. The highest measured concentrations of chlorophyll$b$ and $-c$ were 3.2 and $15.7 \mu \mathrm{g} \cdot 1^{-1}$, respectively. In the anoxic layers, bacteriochlorophylls also varied widely, with an average of $20 \mu \mathrm{g} \cdot 1^{-1}$ and maximum values of approximately $200 \mu \mathrm{g}$. $1^{-1}$ in a narrow layer of the lake just around the deep chlorophyll maximum (DCM). Figure 3C presents the most abundant taxon-specific carotenoids observed in the lake. More than 15 different carotenoids were recovered in the chromatographic analysis for Lake La Cruz. The more relevant carotenoids detected from chlorophytes were zeaxanthin, lutein, violaxanthin, and antheroxanthin. Other relevant carotenoids were zeaxanthin and myxoxantophyll in cyanobacteria, alloxanthin from cryptophytes and fucoxanthin and diatoxanthin from bacillariophytes. Other ubiquitous carotenoids, such as $\beta$-carotene, were also regularly observed in samples. Among bacterial carotenoids, okenone was the most abundant; this carotenoid is characteristic of some purple sulphur bacteria (PSB), with Lamprocystis purpurea being the dominant species in Lake La Cruz. Also observed in the samples were the signature carotenoids of green sulphur bacteria (GSB), isorenieratene and chlorobactene.

The relationships between the chlorophyll- $a$ concentrations measured using HPLC and the estimates made with different spectrophotometric equations are shown in figure 4 and Table 3. The HPLC data are expressed as either the total amount of native chlorophyll- $a$ (Fig. 4, plots on left column) or the sum of the native form and derivatives (plots on right column), which were primarily chlorophyllide- $a$ and pheophytin- $a$, although small amounts of pheophorbides were also present and taken into account. There were important differences in the responses of the equations studied in relation to the depth of the lake, which implies an important component of spatial variability in the water column that yields different accuracies depending on whether samples are from oxic or anoxic water.

The correlations between the spectrophotometric determinations of chlorophyll- $a$ (native plus derivate forms) and the HPLC measurements (Table 3), made for all data in the vertical profile (oxic and anoxic samples), showed that the overall monochromatic and trichromatic equations (Marker, 1972; Strickland \& Parsons 1972; Jeffrey \& Humphrey 1975), although significantly correlated, had low Pearson values and high errors (approximately 25\%) with slopes that strongly underestimate the concentration of chlorophyll- $a$ (with respect to HPLC) when all samples were jointly considered. The spectrophotometric equations with a correction for bacteriochlorophyll (Parkin \& Brock, 1981 and Overmann \& Tilzer, 1989) showed better correlations (higher Pearson values). However, the equation of Parkin \& Brock (1981) had a similar \% error than the monochromatic and trichromatic equations but, in this case, a high overestimation of chlorophyll- $a$ concentration (slope 1.235). Overall, the equation whose predictions best fit all of the data was that given by Overmann \& Tilzer (1989), showing a low error $(1.9 \%)$ and no considerable deviation of the estimated chlorophyll- $a$ concentration (slope 1.019).

For oxic samples, all equations overestimated the spectrophotometric chlorophyll- $a$ concentration with respect to the native chlorophyll- $a$ values (Figs. 4 A, C, E, G, I) measured by HPLC. However, when derivative forms are also considered, as all equations do, monochromatic and trichromatic equations (Marker, 1972; 


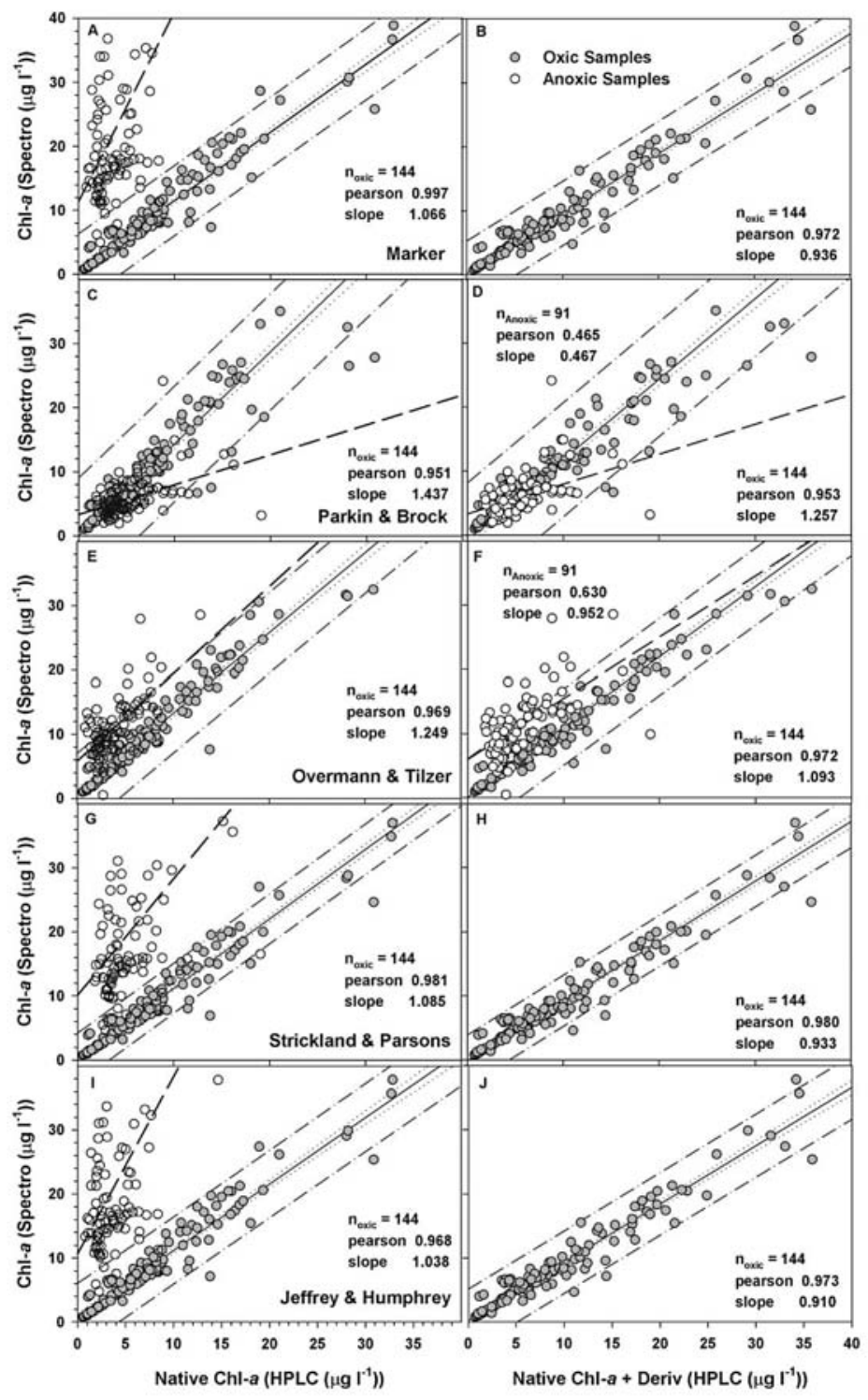

Figure 4. Relationship between the chlorophyll- $a$ concentrations $\left(\mu \mathrm{g} 1^{-1}\right)$ obtained using different spectrophotometric equations and through HPLC. In the left column (A, C, E, G, and I), correlations are shown between the concentrations obtained by the spectrophotometric equations and the concentrations of native chlorophyll- $a$ determined by HPLC (including allomer and epimer) for both oxic and anoxic samples. The right column (B, D, F, H, and J) plots the correlations between the concentrations obtained by spectrophotometric equations and the total chlorophyll- $a$ concentrations determined by HPLC (native plus derivate pigments, chlorophyllide- $a$, pheophytin- $a$ and pheophorbide- $a$ ). Anoxic samples have been excluded for equations that do not include a correction for bacteriochlorophylls and have been maintained only for the equations of Parkin \& Brock (1981) and Overmann \& Tilzer (1989). (Solid line: correlation of oxic samples; dotted line: confidence intervals; dash-dot line: prediction intervals; dash line: correlation of anoxic samples). Relación entre las concentraciones de clorofila-a ( $\left.\mu \mathrm{g} l^{-1}\right)$ obtenidas mediante las diferentes ecuaciones espectrofotométricas estudiadas respecto a las obtenidas por HPLC. En la columna de la izquierda $(A, C, E, G, e$ I) se muestran las correlaciones entre las concentraciones estimadas por las ecuaciones espectrofotométricas y la concentración de clorofila-a nativa medida por HPLC (sumando su alomero y epimero). En la columna derecha ( $B, D, F, H$, y $)$ se muestran las correlaciones entre las concentraciones estimadas por ecuaciones espectrofotométricas y la concentración total de clorofila-a medida por HPLC (sumando a la nativa los pigmentos derivados como clorofilida-a, feofitina-a y feoforbido-a). Las muestras anóxicas han sido excluidas para las ecuaciones sin corrección para bacterioclorofilas y mantenidas solo para Parkin \& Brock (1981) y Overmann \& Tilzer (1989) (Línea continua: Correlación de las muestras óxicas. Línea de puntos: intervalos de confianza. Línea de rayas y puntos: intervalo de predicción. Línea de rayas: correlación de las muestras de anoxia). 


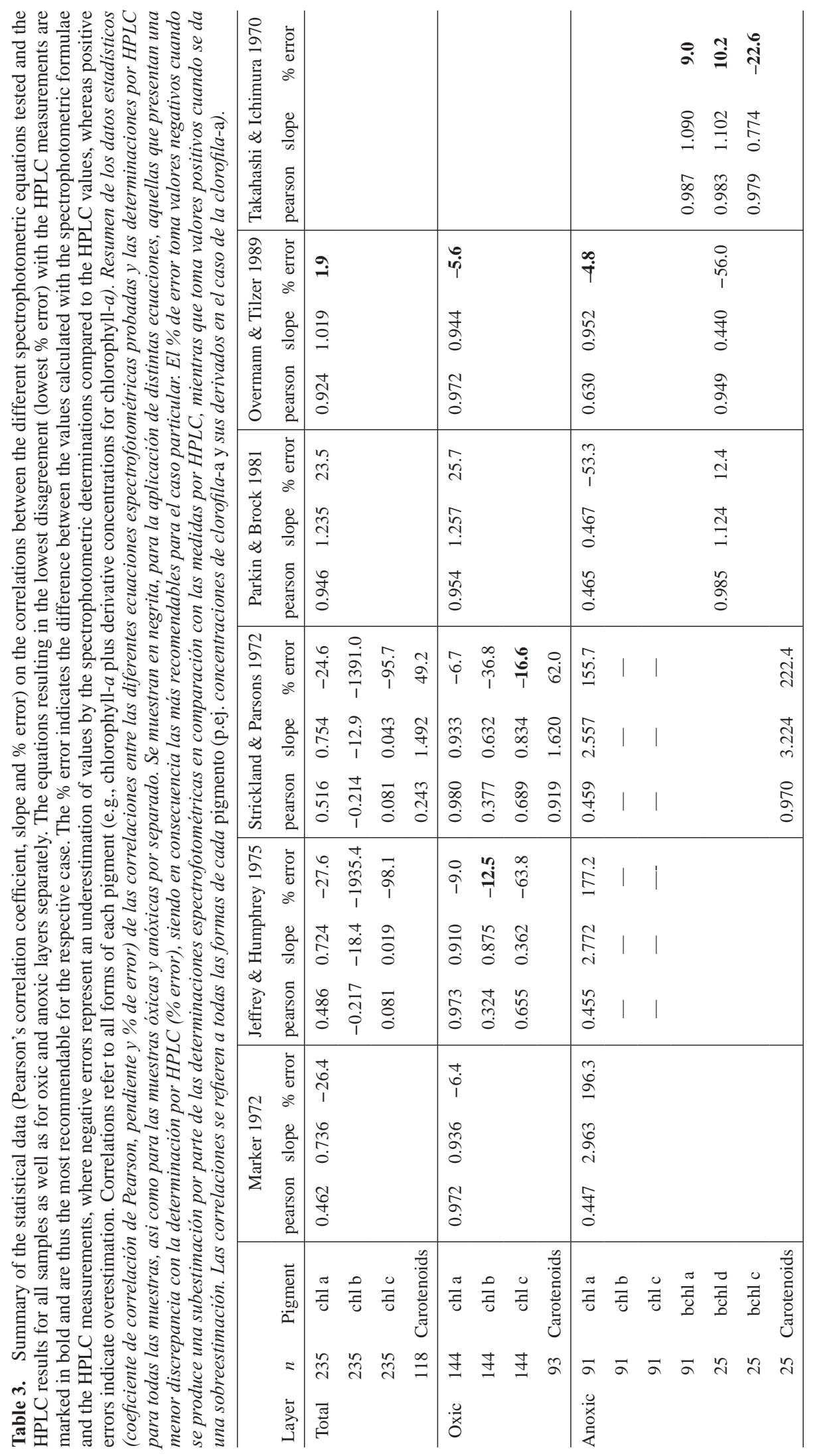



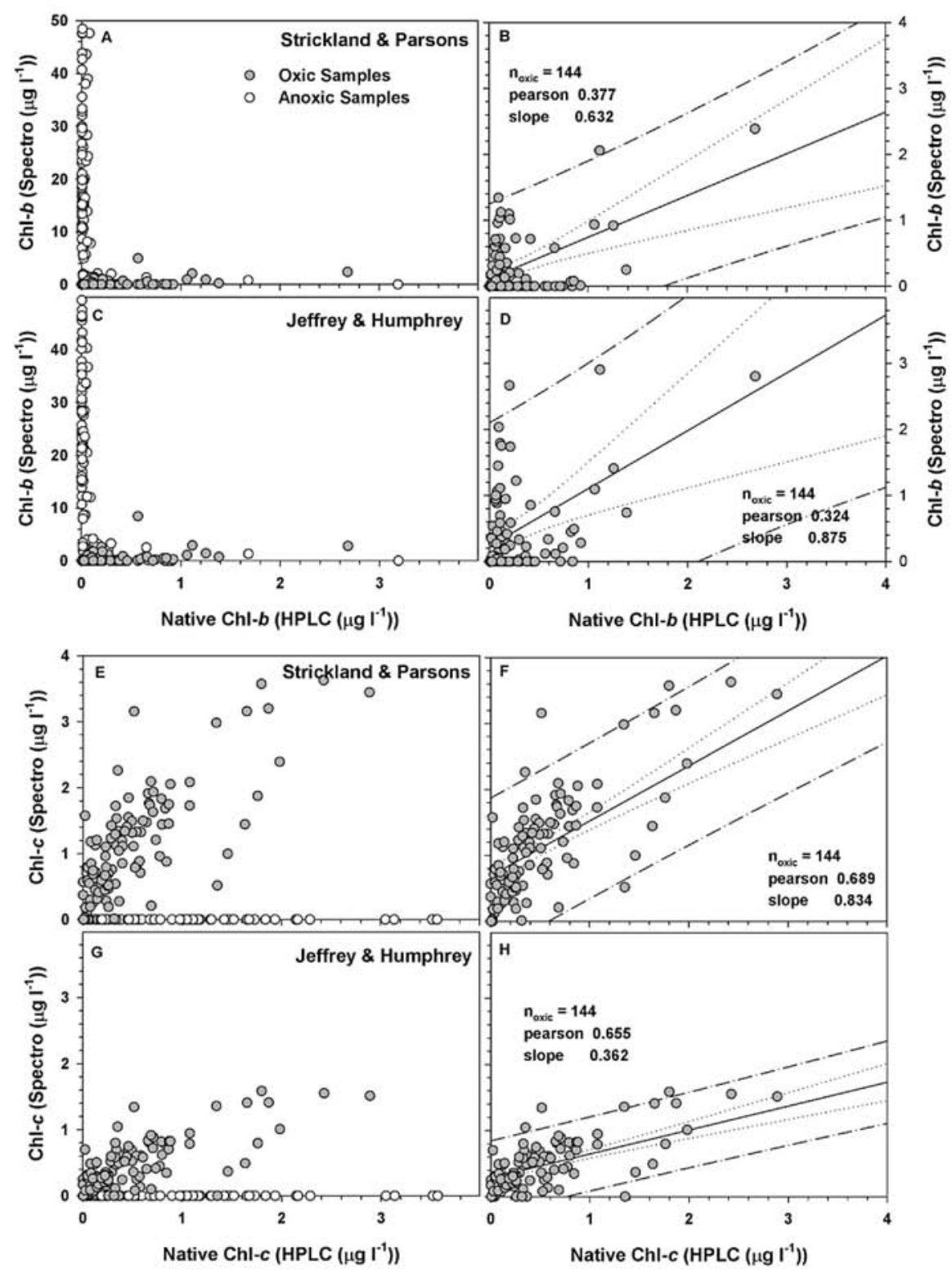

Figure 5. A to D) Relationships between the chlorophyll- $b$ concentrations ( $\left.\mu \mathrm{g}^{-1}\right)$ obtained using the spectrophotometric equations proposed by Strickland \& Parsons (A and B) and by Jeffrey \& Humphrey (C and D) and the concentrations measured using HPLC. E-H) Relationships between the chlorophyll-c concentrations $\left(\mu \mathrm{g}^{-1}\right)$ obtained using the equations of Strickland \& Parsons (E and F) and Jeffrey \& Humphrey $(\mathrm{G}$ and $\mathrm{H})$ and the concentrations measured using HPLC. Note the change of scale in chlorophyll- $b$ plots A-B compared to C-D. (Solid line: correlation of oxic samples; dotted line: confidence intervals; dash-dot line: prediction intervals). No correlation was found when all samples (oxic and anoxic) were included (left plots). The right plots include only oxic samples. A-D) Relación entre las concentraciones $\left(\mu \mathrm{g}^{-1}\right)$ de clorofila-b obtenidas mediante las ecuaciones espectrofotométricas de Strickland \& Parsons $\left(\begin{array}{l}A \\ \text { y B }\end{array}\right.$ ) y Jeffrey \& Humphrey $(C$ y D) respecto a las obtenidas por HPLC. E-H) Relación entre las concentraciones ( $\mu g$ $\left.l^{-1}\right)$ de clorofila-c obtenidas mediante las ecuaciones espectrofotométricas de Strickland \& Parsons (E y F) y Jeffrey \& Humphrey $(G$ y $H)$ respecto a las obtenidas por HPLC. Nótese el cambio de escala para las figuras de la clorofila-b, A-B, respecto a las $C-D$, (Línea continua: Correlación de las muestras óxicas. Línea de puntos: intervalos de confianza. Línea de rayas y puntos: intervalo de predicción). Cuando se incluyeron todas las muestras (óxicas y anóxicas, gráficas de la izquierda) no se encontró ninguna correlación, en las gráficas de la derecha se incluyen solo las muestras óxicas. 

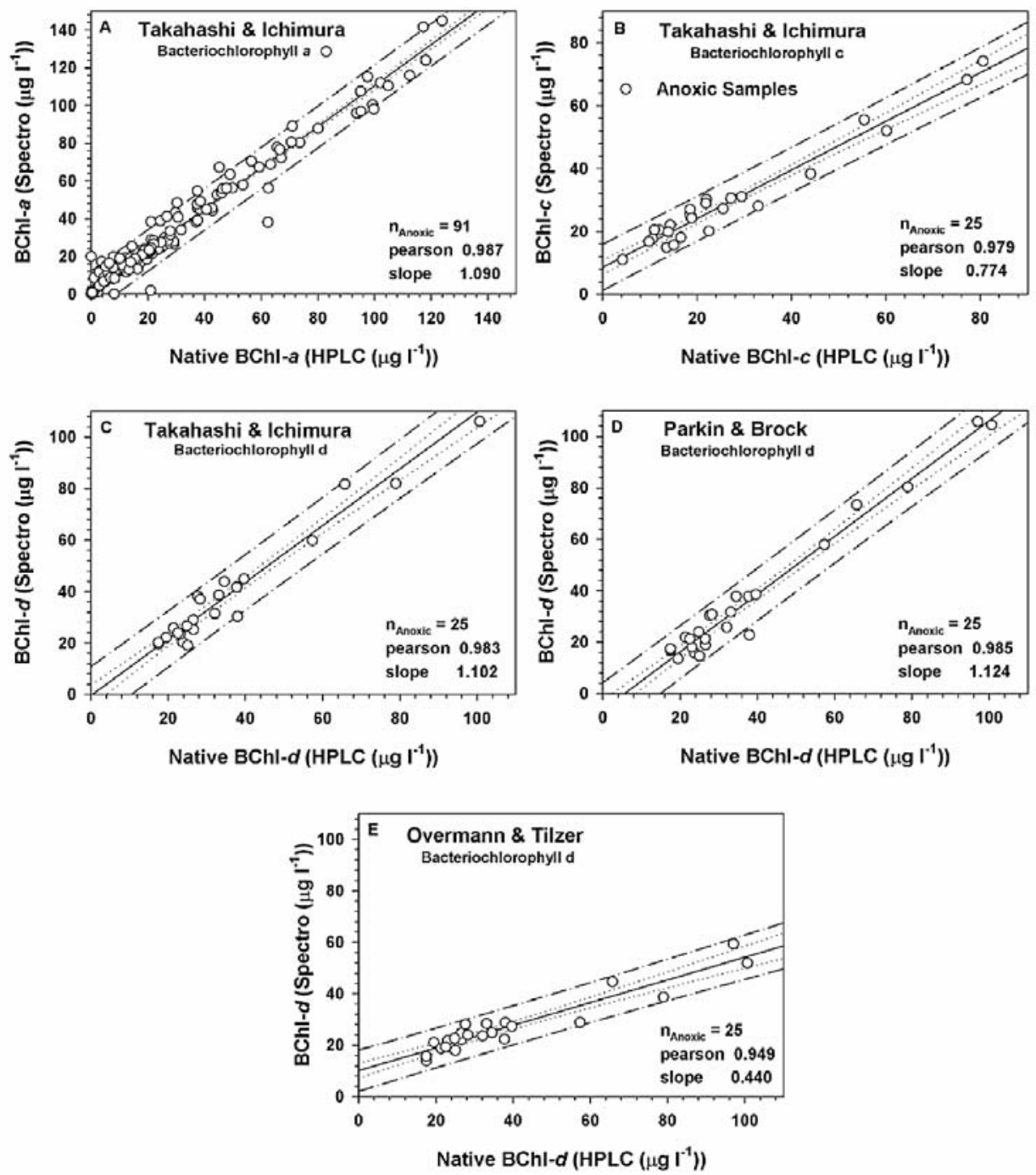

Figure 6. Plots include only the anoxic samples. A) Relationship between the bacteriochlorophyll- $a$ concentrations ( $\mu$ g $1^{-1}$ ) obtained by Takahashi \& Ichimura's spectrophotometric equation and those obtained by HPLC. B) Relationship between the bacteriochlorophyll- $c$ concentrations ( $\mu \mathrm{g} \mathrm{l}^{-1}$ ) obtained by Takahashi \& Ichimura's spectrophotometric equation and those obtained by HPLC. C-D-E) Relationship between the bacteriochlorophyll- $d$ concentrations $\left(\mu \mathrm{g}^{-1}\right)$ obtained using the spectrophotometric equations of Takahashi \& Ichimura (C) Parkin \& Brock (D) and Overmann \& Tilzer (E) and those obtained using HPLC. (Solid line: correlation of anoxic samples; dotted line: confidence intervals; dash-dot line: prediction intervals). Incluye solo muestras anóxicas. A) Relación entre las concentraciones de bacterioclorofila-a $\left(\mu \mathrm{g} l^{-1}\right)$ obtenidas mediante la ecuación espectrofotométrica de Takahashi \& Ichimura respecto a las obtenidas por HPLC. B) Relación entre las concentraciones de bacterioclorofila-c $\left(\mu g l^{-1}\right)$ obtenidas mediante la ecuación espectrofotométrica de Takahashi \& Ichimura respecto a las obtenidas por HPLC. C-D-E) Relación entre las concentraciones de bacterioclorofila-d $\left(\mu \mathrm{g} l^{-1}\right)$ obtenida mediante las ecuaciones espectrofotométricas de Takahashi \& Ichimura $(C)$ Parkin \& Brock (D) y Overmann \& Tilzer (E) respecto a las obtenidas por HPLC. (Línea continua: Correlación de las muestras anóxicas. Línea de puntos: intervalos de confianza; línea de rayas y puntos: intervalo de predicción).

Strickland \& Parsons 1972; Jeffrey \& Humphrey 1975) underestimated chlorophyll- $a$ (plus derivatives) concentrations (Figs. 4 B, H, J). Because spectrophotometric equations include the deter- mination of all forms (native plus derivatives), Table 3, which synthesises the results of the application of the different equations, was made by considering the correlations of spec- 
trophotometric determinations with the HPLC concentrations of native plus derivate forms of chlorophyll- $a$. Concerning the equations that correct chlorophyll- $a$ concentration for the presence of bacteriochlorophyll- $d(d+e)$, that of Parkin \& Brock (1981) exhibited a high error (25.7 \%), overestimating chlorophyll- $a$. Although for oxic samples all but Parkin \& Brock's equation for chlorophyll- $a$ produced relatively low errors (under $10 \%$ ), the best values were again provided by the Overmann \& Tilzer (1989) equation, with an error of $5.6 \%$, whereas the most-used Jeffrey \& Humphrey (1975) equation produced an error of $9.0 \%$.

Concerning the anoxic samples, no significant correlation was found for the monochromatic and trichromatic equations that did not include a bacteriochlorophyll- $d$ correction for chlorophyll$a$ concentration (dashed line in Figs. 4 A, C, E, $\mathrm{G}, \mathrm{I}$ ), which resulted in large errors (Table 3 ). Those equations are thus unsuitable for determining chlorophyll- $a$ in anoxic waters presenting green photosynthetic bacteria. For the equations with a bacteriochlorophyll-d correction (Figs. 4 D, F), that of Parkin \& Brock (1981) exhibited a low Pearson correlation $(r=0.465)$, low slope (0.467), and high error (53\%), with a strong underestimation with respect to HPLC values. Again, Overmann \& Tilzer's (1989) equation showed the best correlation $(r=0.630)$, with a good slope $(0.952)$ and low error $(4.8 \%)$.

Figure 5 presents the relationship between the two analytical methods, but in this case for the measurement of chlorophyll- $b$ and $-c$, for which only the trichromatic equations of Strickland \& Parsons (1972) and Jeffrey \& Humphrey (1975) had previously been proposed. As with chlorophyll- $a$, the trichromatic equations were inadequate in predicting the concentrations of these pigments in the anoxic layers, where chlorophyll- $b$ and $-c$ likely represent settling algae. When all samples were jointly considered (Fig. 5, plots on left, Table 3), there was again no correlation between the spectrophotometric and
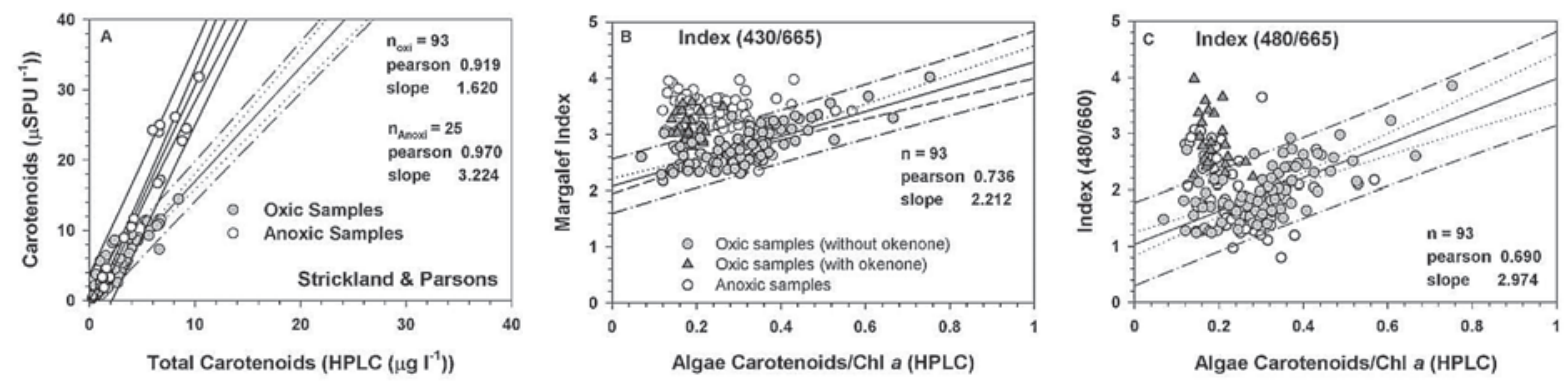

Figure 7. Relationships between the different carotenoid indices obtained by spectrophotometric formulae (relative or absorbance units) and the carotenoid concentrations ( $\mu \mathrm{g}^{-1}$ ) measured by HPLC. A) Correlation between the Strickland \& Parsons (1972) estimation of carotenoid abundance and the total carotenoid concentration $\left(\mu \mathrm{g} \mathrm{l}^{-1}\right)$ measured by HPLC for oxic and anoxic samples. B) Correlation, for oxic samples not presenting okenone, between the absorbance 430/665 index and the ratio of total HPLC-measured algal carotenoid concentration to total (native plus derivatives) chlorophyll-a concentration. C) Correlation, for oxic samples not presenting okenone, between the absorbance index 480/665 and the ratio of total HPLC-measured algal carotenoid concentration to total chlorophyll-a concentration (solid lines in plot A correspond to either the oxic and anoxic samples, whereas in plots B and $\mathrm{C}$ they correspond only to oxic samples not presenting okenone. Dotted line: confidence intervals; dash-dot line: prediction intervals). Relación entre los diferentes índices de carotenos obtenidos por espectrofotometría (unidades relativas o de absorbancia) y las concentraciones de carotenos $\left(\mu g l^{-1}\right)$ medidas por HPLC. A) Correlación entre la estimación de la abundancia de carotenos estimada mediante la expresión de Strickland \& Parsons (1972) y la concentración total de carotenos ( $\left.\mu g l^{-1}\right)$ medida por HPLC para las muestras óxicas y anóxicas. B) Correlación, para las muestras óxicas que no presentan okenona, entre el índice de absorbancia 430/665 y el ratio entre las concentraciones de carotenos algales respecto a las concentraciones de clorofila-a total (nativa más derivados) medidas por HPLC. C) Correlación, para las muestras óxicas que no presentan okenona, entre el índice de absorbancia $480 / 665$ y el ratio entre las concentraciones de carotenos algales respecto a las concentraciones de clorofila-a total medidas por HPLC. (Línea continua: en el gráfico A corresponde a las muestras óxicas y, por separado, a las muestras anóxicas, mientras que en los gráficos B y C corresponde solo a las muestras óxicas que no presentan okenona, Línea de puntos: intervalos de confianza; línea de rayas y puntos: intervalo de predicción). 
HPLC measures. Even when considering only the oxic samples (Fig. 5, plots on the right, and Table 3), the accuracy of the spectrophotometric determinations was very low, as the concentrations of these pigments in the lake were also low.

Concerning bacteriochlorophylls, (Fig. 6), Takahashi \& Ichimura (1970) provided an equation for the calculation of bacteriochlorophyll- $a$ that fits well with HPLC determinations, showing a high correlation coefficient. This correlation is facilitated by the higher number of samples for the analysis compared to the lower number for other bacteriochlorophylls. The equations of Takahasi \& Ichimura (1970), which are the most extensively used to estimate bacterial pigments, slightly overestimated both bacteriochlorophyll- $a$ and bacteriochlorophyll- $d$ by approximately $10 \%$, whereas bacteriochlorophyll-c was underestimated by approximately $23 \%$. A lower accuracy was observed for the calculation of bacteriochlorophyll- $d$ by means of the Parkin \& Brock (1981) equation, which overestimated concentrations by $12 \%$. By contrast, the equation of Overmann \& Tilzer (1989) greatly underestimated bacteriochlorophyll-d concentrations by more than $50 \%$.

The comparison between carotenoid quantifications performed on non-purified extracts using the Strickland \& Parsons (1972) equations and through HPLC determinations are shown in figure 7 . Both direct quantifications and absorbance ratios were also sensitive to the samples' origin. Although a statistically significant correlation was observed when comparing the total carotenoids measured with the equation of Strickland \& Parsons (1972) with the measures obtained by HPLC, the different slopes of 1.62 for oxic layers and 3.22 for anoxic layers indicate that the response of Strickland \& Parsons' equations is different when bacterial carotenoids are involved. Thus, these equations are not suitable to be used indistinctly for oxic and anoxic samples. On the other hand, the two dual-wavelength absorbance ratios (i.e., 430/665 and 480/665) (Margalef, 1983) exhibited moderately good correlations for only the epilimnetic samples, whereas the metalimnetic and hy- polimnetic samples (that include the bacterial carotenoid okenone) did not show any significant relationships with the carotenoid/chlorophyll- $a$ ratios estimated from the HPLC measures.

\section{DISCUSSION}

Although HPLC analyses provide higher precision and improve pigment characterisation compared to routine spectrophotometric methods (Wright \& Jeffrey, 2006), the former are also more expensive and time-consuming. Thus, for many applications, direct spectrophotometric measures may offer a high enough level of precision to obtain optimum results. Our examination of cited works in the Thomson Reuters (formerly ISI) Web of Knowledge reveals that at present, spectrophotometric equations are extensively used (Fig. 1). The number of citations is continuously increasing for some of these equations, such as those proposed by Jeffrey \& Humphrey (1975) and Strickland \& Parsons (1972) in the mid-1970s. This preference for spectrophotometric methods is evident because routine spectrophotometric procedures avoid cost and time compared to HPLC, but the inherent inaccuracies of the method require caution when applying the different formulae and when interpreting the results, particularly when the study involves stratified water columns. Several studies, including ours, demonstrate that the validity of some equations depends on the origin of the samples and that the presence or absence of certain pigment forms may cause the accuracy of the determination to vary. For example, the absorption characteristics of chlorophyll- $a$ derivatives introduce some bias into the quantification of native chlorophyll-a (Salinas, 1988; Rowan 1989; Jacobsen \& Rai, 1990; Pinckney et al., 1994; Ritchie 2008). To explore this issue, we compared the linear correlations of quantifications obtained by both considering and not considering these chlorophyll- $a$ derivatives. When chlorophyll- $a$ derivatives were excluded from the HPLC addition of pigment forms (Fig. 4, left plots), all equations overestimated the native chlorophyll- $a$ concentrations due to 
the presence of these degradation derivatives, although the overestimates were generally less than $10 \%$. However, upon the consideration of derivative forms in the HPLC measurements, all equations other than dichromatic ones (those of Parkin \& Brock, 1981, and Overmann \& Tilzer, 1989) underestimated the HPLC measurements. It has previously been suggested that the use of spectrophotometric methods can be acceptable if degraded forms represent less than $5 \%$ of total chlorophyll- $a$ (Jodłowska \& Latała, 2011). The error of our estimates was commonly less than $10 \%$ (Fig. 4), which could be explained by the presence of these derivatives, except for the case of the Parkin \& Brock's equation that consistently and greatly overestimates chlorophyll- $a$ concentrations.

There are also spectrophotometric protocols, not tested in this study, that allow the correction of chlorophyll- $a$ concentrations with respect to their degraded compounds through a previous acidification step (Lorenzen, 1967). By means of this acidification, native chlorophyll- $a$ is transformed into phaeophytin- $a$. Chlorophyllide- $a$ is the result of the loss of the phytol chain and is a common degraded form of chlorophyll- $a$ whose occurrence has been associated with cell senescence due to the enzymatic activity of chlorophyllases (Louda et al., 1998, 2002) and/or disruption produced by predation (Barlow et al., 1988). In Lake La Cruz, high concentrations of this pigment are usually associated with the metalimnetic deep chlorophyll maximum, which invalidates the use of such methods for the studied lake, as the presence of high quantities of chlorophyllide- $a$ in the extracts detracts from the validity of the results even after acidification (Plante-Cuny et al., 1993). For that reason, we did not evaluate such methods.

In highly stratified lakes, additional interference in the quantification of chlorophyll- $a$ is generated by spectral overlap with bacteriochlorophylls. These pigments occur primarily in the anoxic and microaerobic layers, where photosynthetic sulphur bacteria thrive. This would explain why neither the monochromatic (Marker, 1972) nor the trichromatic (Strickland \& Parsons, 1972; Jeffrey \& Humphrey, 1975) equations that we tested produced good estimates of chlorophyll- $a$ for the anoxic layers of the lake. In the early 1980s, Parkin \& Brock (1981) proposed a dichromatic equation to estimate chlorophyll- $a$ concentrations in the presence of bacteriochlorophyll- $d$, which is the main source of interference for chlorophyll- $a$ concentration estimations. Since then, this equation has been widely used in these types of lakes. The effectiveness of this equation was later challenged by Overmann \& Tilzer (1989), who proposed an alternative algorithm. In our study, the equation of Parkin \& Brock (1981) did not correctly approximate chlorophyll- $a$ concentrations when bacteriochlorophyll- $d$ was present, and we do not recommend its use in such cases. The equation of Overmann \& Tilzer (1989), however, offered the best results in measuring chlorophyll- $a$ concentrations regardless of the sample's origin (oxic or anoxic water), and it was the only equation that produced good estimations for anoxic samples. In contrast, for the oxic samples, no equations except that of Parkin \& Brock (1981) deviated notably from the linear distribution, thus indicating a high measurement accuracy of these equations compared to the results of HPLC and making any of these equations suitable for the determination of chlorophyll- $a$ in oxic waters.

Trichromatic equations are widely used in spectrophotometric procedures for the determination of chlorophyll- $b$ and - $c$ (Jeffrey et al., 1997), which provide chemotaxonomic information concerning phytoplankton community composition. The two most-used equations were defined by Parsons \& Strickland (1963) (usually reported by Strickland \& Parsons, 1972 and later almost identically assumed by SCOR-UNESCO, 1966) and by Jeffrey \& Humphrey (1975). The equation of Jeffrey \& Humphrey (1975) is used even more often, most likely because it is the equation recommended by the US EPA. However, a critical aspect of these trichromatic equations is that they are not accurate in estimating pigments at low concentrations. Unicellular picocyanobacteria and photosynthetic bacteria dominate the phytoplankton community of the meromictic Lake La Cruz (Rodrigo et al., 2001; Camacho et al., 2003). By contrast, algal groups 
containing chlorophyll- $b$ (i.e., chlorophytes) or chlorophyll- $c$ (i.e., bacillariophytes and chrysophytes) regularly exhibit lower abundances in the studied lake, which implies that the possible use of these equations is complicated by these pigment concentrations being near or below the equations' resolution limit. This appears to particularly affect the estimation of chlorophyll- $b$, which in our case produced the worst statistical results, contrasting with Ritchie's (2008) observations of a lower accuracy of these equations for the calculation of chlorophyll- $c$ compared to chlorophyll- $b$. Moreover, in lake layers where green photosynthetic bacteria occur, such as the metalimnion and hypolimnion of Lake La Cruz, bacteriochlorophylls are likely producing this bias because of the spectra overlap, which can be observed in figure 2. In our case, chlorophyll$b$ estimation is more sensitive to this bias compared to chlorophyll- $c$.

To assess bacteriochlorophyll ( $a, c$ and $d$ ) concentrations, we applied the equations of Takahashi \& Ichimura (1970), which are the most commonly utilised in freshwater ecosystems. We also assessed the dichromatic equations of Parkin \& Brock (1981) and Overmann \& Tilzer (1989), which were designed for the calculation of chlorophyll- $a$ concentration when bacteriochlorophyll- $d$ is present and also allow for the estimation of the concentrations of bacteriochlorophyll- $d$ and $-e$. Bacteriochlorophyll-e was not present in samples from Lake La Cruz, as confirmed by the HPLC analysis; under these circumstances, we assume that the equation of Overmann \& Tilzer (1989) could be used to measure the concentration of bacteriochlorophyll- $d$. During the mixing period, photosynthetic sulphur bacteria in Lake La Cruz might incidentally occur in oxic layers due to the lack of control of buoyancy and the formation of aggregates that can remain for a long time in the mixolimnion; however, such bacteria naturally develop in the anoxic monimolimnion and hypolimnion when sufficient light reaches these sulphide-containing depths (Casamayor et al., 2011). It is for this reason that correlations were only explored for the anoxic layers of the lake (Fig. 6). In contrast with chlorophyll- $a$, the derivatives of these bacterial pigments are present only in very low amounts, making any correction unnecessary. Bacteriochlorophyll- $a$ is found in purple sulphur bacteria (PSB). In Lake La Cruz, Lamprocystis purpurea dominates among other PSB species (Casamayor et al., 2011). The correlations obtained for this pigment between the equations of Takahashi \& Ichimura (1970) and the HPLC determinations are in our case statistically satisfactory, indicating an underestimation of the bacteriochlorophyll- $a$ concentration by only $8 \%$. Concerning bacteriochlorophyll- $c$ and $-d$, which occur in green sulphur bacteria (GSB), among which Chlorobium clathratiforme is abundant in Lake La Cruz, the results obtained with the equations of Takahashi \& Ichimura (1970) show a better fit for bacteriochlorophyll$d$. In this case, bacteriochlorophyll- $c$ was here underestimated by approximately $23 \%$. Concerning the other equations, that of Parkin \& Brock (1981) produced a good correlation for bacteriochlorophyll- $d$, whereas the equation of Overmann \& Tilzer (1989) appears to notably underestimate the concentration of this pigment. For this last result, it should be noted that Overmann \& Tilzer's equation was designed to assess mixtures of bacteriochlorophyll- $d$ and $-e$, which is not our case.

There are several analytical approaches to assess the carotenoid-to-chlorophyll ratios in phytoplankton. These include simple ratios of absorbance among specific wavelengths (e.g., $480 / 665 \mathrm{~nm}$ or $430 / 665 \mathrm{~nm}$ ) that assess the carotenoid-to-chlorophyll- $a$ relationship (Margalef, 1983), as well as quantitative methods such as HPLC determination. The former are rarely reported in the scientific literature; however, they are still formally used in management and technical studies. One of the first attempts to spectrophotometrically quantify carotenoid concentrations was made by Richards \& Thomson (1952), but this produced inadequate results when diatoms and/or chrysophytes occurred in samples. Strickland \& Parsons (1972) proposed an equation that partially solved this problem; however, it assumed that the relationship among the concentrations of different carotenoids re- 
mains somewhat constant throughout the water column, which is not true for highly stratified lakes such as Lake La Cruz. Although the wavelengths used in these equations are within the ranges of maximum absorption of all carotenoids, a notable variation in the relative composition of carotenoids with depth, such as would be expected for highly stratified lakes, can introduce an important bias. In any case, carotenoid-to-chlorophyll- $a$ ratios can be suitable for qualitative analyses and represent readily obtainable optical signatures that can be used as proxies for some phytoplankton community properties. However, our results indicate that only epilimnetic waters can be accurately analysed in this way due to the interference of some bacterial carotenoids such as okenone in microaerophilic and anoxic waters.

In summary, our results demonstrate that in highly stratified aquatic systems, the concentrations of only some algal and bacterial photosynthetic pigments can be estimated with an appropriate accuracy using spectrophotometric algorithms. Furthermore, the use of only one of these types of equations is not always recommended for the entire water column, but the change from one equation to another depends on the mixture and relative abundance of the different photosynthetic microorganisms. In any case, for chlorophyll- $a$ determinations, we found the equation by Overmann \& Tilzer (1989) to perform the best under all circumstances; thus, we recommend its use for stratified water columns showing vertical stratification of photosynthetic microorganisms. Concerning bacteriochlorophylls, the formulae by Takahahi \& Ichimura perform well in anoxic waters, where phototrophic bacteria thrive. Similar considerations for other pigments, such as chlorophyll- $b$ and $-c$, and carotenoid concentrations or ratios can be made by reviewing the information synthesised in Table 3. This table summarises the strength of each equation when applied to a stratified system such as our model lake and could serve as a reference for the selection of the most appropriate equation when spectrophotometric methods are used for photosynthetic pigment determinations.

\section{ACKNOWLEDGEMENTS}

The research of AC, AP, and CR is currently supported by Project CGL2012-38909 (ECOLAKE) of the Spanish Ministerio de Economia y Competitividad. AP received a scholarship from Caja de Ahorros del Mediterraneo-Proyecto Agua (CAM). We thank Esther Dominguez for her helpful assistance with the laboratory work.

\section{REFERENCES}

APHA-AWWA-WEF. 2005. Standard methods for the examination of water and watershed. $21^{\text {th }}$ edition. American public health association. Washington DC, USA. 1200 pp.

ARAR, E. J. 1997. Determination of chlorophylls $a$ and $b$ and identification of other pigments of interest in marine and freshwater algae using high performance liquid chromatography with visible wavelength detection. Method 447.0, U.S. Environmental Protection Agency.

BARLOW, R. G., P. H. BURKILL \& R. F. C. MANTOURA. 1988. Grazing and degradation of algal pigments by marine protozoan Oxyrrhis marina. Journal of Experimental Marine, 119: 119-129.

CAMACHO, A., J. PEREZ, A. CHICOTE, M. FLORIN, M. M. SQUIRES, C. LEHMANN \& R. BACHOFEN. 2001. Microbial microstratification, inorganic carbon photoassimilation and dark carbon fixation at the chemocline of the meromictic Lake Cadagno (Switzerland) and its relevance to the food web. Aquatic Sciences, 63: 91-106.

CAMACHO, A., A. PICAZO, M. R. MIRACLE \& E. VICENTE. 2003. Spatial distribution and temporal dynamics of picocyanobacteria in a meromictic karstic lake. Archiv für Hydrobiologie Supplementband, 148: 171-184.

CASAMAYOR, E. O., M. LLIROS, A. PICAZO, A. BARBERÁN, C. M. BORREGO \& A. CAMACHO. 2011. Contribution of deep dark fixation processes to overall $\mathrm{CO}_{2}$ incorporation and large vertical changes of microbial populations in stratified karstic lakes. Aquatic Sciences, 74: 61-75.

DOS SANTOS, A. C. A., M. C. CALIJURI, E. M. MORAES, M. A. T. ADORNO, P. B. FALCO, D. P. CARVALHO, G. L. B. D. P., DEBERDT, G. L. B. \& BENASSI, S. F. 2003. Comparison of three methods for chlorophyll determination: spec- 
trophotometry and fluorimetry in samples containing pigment mixtures and spectrophotometry in samples with separate pigments through High Performance Liquid Chromatography. Acta Limnologica Brasiliensia, 15: 7-18.

FOPPEN, F. H. 1971. Tables for identification of carotenoid pigments. Chromatographic Reviews, 14: 133-298.

JACOBSEN, T. R. \& H. RAI. 1990. Comparison of spectrophotometric, fluorometric and High Performance Liquid Chromatography Methods for Determination of chlorophyll a in aquatic samples: Effects of solvent and extraction procedures. Internationale Revue gesamten Hydrobiologie, 75: 207-217.

JEFFREY, S. W. \& G. F. HUMPHREY. 1975. New spectrophotometric equations for determining chlorophylls a, b, c1 and c2 in higher plants, algae and natural phytoplankton. Biochemie und Physiologie der Pflanzen, 167: 191-194.

JEFFREY, S. W., MANTOURA, R. F. C. \& S.W. WRIGHT. 1997. Phytoplankton pigments in oceanography: guidelines to modern methods. UNESCO, Paris, 661 pp.

JODŁOWSKA, S. \& A. LATAŁA. 2011. The comparison of spectrophotometric method and high performance liquid chromatography in photosynthetic pigments analysis. Online Journal of Biological Sciences, 11: 63-69.

LATASA, M., R. R. BIDIGARE, M. E. ONDRUSEK, AND M. C. KENNICUTT II. 1996. HPLC analysis of algal pigments: a comparison exercise among laboratories and recommendations for improved analytical performance. Marine Chemistry, 51: 315-324.

LORENZEN, C. J. 1967. Determination of chlorophyll and pheopigments: spectrophotometric equations. Limnology \& Oceanography, 12: 343-346.

LOUDA, J. W., J. L. LEI LIU, M. N. WINFREE \& E. W. BAKER. 1998. Chlorophyll-a degradation during cellular senescence and death. Organic Geochemistry, 29: 1233-1251.

LOUDA, J. W., LIU, L., \& E. W. BAKER. 2002. Senescence and deathrelated alteration of chlorophylls and carotenoids in marine phytoplankton. Organic Geochemistry, 33: 1635-1653.

MACLULICH, J. H. 1986. Experimental evaluation of methods for sampling and assaying intertidal epilithic microalgae. Marine Ecology Progress Series, 34: 275-280.
MANTOURA, R. F. C., \& C. A. LLEWELLYN. 1983. The rapid determination of algal chlorophyll and carotenoid pigments and their breakdown products in natural waters by reverse-phase highperformance liquid chromatography. Analytica Chimica Acta, 151: 297-314.

MANTOURA, R. F. C., S. W. JEFFREY, C. A. LlEWEllyN, H. ClaUSTRE, \& C. E. MORALES. 1997. Comparison between spectrophotometric, fluorometric and HPLC methods for chlorophyll analysis. In Phytoplankton pigments in oceanography: guidelines to modern methods. S. W. Jeffrey et al. (eds.). 361-380. UNESCO, Paris.

MARGALEF, R. 1983. Limnologia. Ediciones Omega, S.A., Barcelona, Spain.

MARKER, A. F. H. 1972. The use of acetone and methanol in the estimation of chlorophyll in the presence of phaeophytin. Freshwater Biology, 2: 361-385.

MIRACLE, M. R., E. VICENTE \& C. PEDRÓSALIÓ. 1992. Biological studies of Spanish meromictic and stratified karstic lakes. Limnetica, 8: 59-77.

MURRAY, A. P., C. F. GIBBS, A. R. LONGMORE \& D. J. FLETT. 1986. Determination of chlorophyll in marine waters: intercomparison of a rapid HPLC method with full HPLC, spectrophotometric and fluorometric methods. Marine Chemistry, 19: 211227.

OVERMANN, J. R. \& M. M. TILZER. 1989. Control of primary productivity and the significance of photosynthetic bacteria in a meromictic kettle lake. Mittlerer Buchensee, West-Germany. Aquatic Sciences, 51: 261-278.

PARKIN, T. \& T. BROCK. 1981. Photosynthetic bacterial production and carbon mineralization in a meromictic lake. Archiv für Hydrobiologie, 91: 366-382.

PARSONS, T. R. \& J. D. H. STRICKLAND. 1963. Discussion of spectrophotometric determination of marine-plant pigments, with revised equations for ascertaining chlorophylls and carotenoids. Journal of Marine Research, 21: 155-163.

PINCKNEY, J., R. PAPA \& R. ZINGMARK. 1994. Comparison of high-performance liquid chromatographic, spectrophotometric, and fluorometric methods for determining chlorophyll a concentrations in estuarine sediments. Journal of Microbiological Methods, 19: 59-66. 
PINCKNEY, J. L., D. F. MILLIE, K. E. HOWE, H. W. PAERL \& J. P. HURLEY.1996. Flow scintillation counting of 14C-labeled microalgal photosynthetic pigments. Journal of Plankton Research, 18: 1867-1880.

PLANTE-CUNY, M. R., C. BARRANGUET, D. BONIN \& C. GRENZ. 1993. Does chlorophyllide a reduce reliability of chlorophyll a measurements in marine coastal sediments? Aquatic Sciences, 55: 19-30.

RICHARDS, F. A. \& T. G. THOMPSON. 1952. The estimation and characterization of plankton populations by pigment analysis. II. A spectrophotometric method for the estimation of plankton pigments. Journal of Marine Research, 11: 156-172.

RITCHIE, R. J. 2006. Consistent sets of spectrophotometric chlorophyll equations for acetone, methanol and ethanol solvents. Photosynthesis Research, 89: 27-41.

RITCHIE, R. J. 2008. Universal chlorophyll equations for estimating chlorophylls $a, b, c$, and $d$ and total chlorophylls in natural assemblages of photosynthetic organisms using acetone, methanol, or ethanol solvents. Photosynthetica, 46: 115-126.

RODRIGO, M. A., E. VICENTE \& M. R. MIRACLE. 2000. The role of light and concentration gradients in the vertical stratification and seasonal development of phototrophic bacteria in a meromictic lake. Archiv für Hydrobiologie, 148: 533-548.

RODRIGO, M. A., M. R. MIRACLE \& E. VICENTE. 2001. The meromictic Lake La Cruz (Central Spain). Patterns of stratification. Aquatic Sciences, 63: 406-416.

ROWAN, K. 1989. Photosynthetic Pigments of Algae. Cambridge University Press.

SALINAS, J. T. 1988. A critical comparison of methods for the determination of phytoplankton chlorophyll. Ph.D. Thesis. Oregon State University, U.S.A.

SCHAGERL, M., \& G. KÜNZL. 2007. Chlorophyll $a$ extraction from freshwater algae $a$ reevaluation. Biologia, 62: 270-275.

SCOR-UNESCO. 1966. Determination of photosyn- thetic pigments in seawater. Monographs on Oceanographic Methodology, UNESCO, Paris, vol. 1, p.11-18.

SHIMURA, S. \& Y. FUJITA. 1975. Changes in the activity of fucoxanthin-excited photosynthesis in the marine diatom Phaeodactylum tricornutum grown under different culture conditions. Marine Biology, 33: 185-194.

SOLOVCHENKO, A. E., I. KHOZIN-GOLDBERG, Z. COHEN \& M. N. MERZLYAK. 2009. Carotenoid-to-chlorophyll ratio as a proxy for assay of total fatty acids and arachidonic acid content in the green microalga Parietochloris incise. Journal of Applied Phycology, 21: 361-366.

STAL, L. J., H. VAN GEMERDEN \& W. E. KRUMBEIN. 1984. The simultaneous assay of chlorophyll and bacteriochlorophyll in natural microbial communities. Journal of Microbiological Methods, 2: 295-306.

STEENBERGEN, C. L. M. \& H. J. KORTHALS. 1982. Distribution of phototrophic microorganisms in the anaerobic and microaerophilic strata of Lake Vechten (The Netherlands). Pigment analysis and the role of primary production. Limnology \& Oceanography, 27: 883-895.

STRICKLAND, J. D. H. \& T. R. PARSONS. 1972. A Practical Handbook of Seawater Analysis. 2nd ed., Bull. Fish. Res. Bd. Can. No. 167, 310 pp.

TAKAHASHI, M. \& S. ICHIMURA. 1970. Photosynthetic properties and growth of photosynthetic sulfur bacteria in lakes. Limnology \& Oceanography, 15: 929-944.

VICENTE, E. \& M. R. MIRACLE. 1988. Physicochemical and microbial stratification in a meromictic karstic lake of Spain. Verhandlungen Internationale Vereinigung für Theoretische und Angewandte Limnologie, 23: 522-529.

WRIGHT, S. W. \& S. W. JEFFREY. 2006. Pigment markers for phytoplankton production. In: The handbook of environmental chemistry Volume 2. Marine organic matter: Biomarkers, isotopes and DNA. J. K. Volkman (ed.): 71-104. Springer Verlag, Basel. 